\title{
Identifikasi Konsep Arsitektur Hijau di Permukiman DAS Brantas Kelurahan Penanggungan Malang
}

\author{
Damayanti Asikin, Rinawati P. Handajani, Sigmawan Tri Pamungkas, Haru A. \\ Razziati
}

Jurusan Arsitektur Fakultas Teknik Universitas Brawijaya Malang

Jl. Mayjend Haryono No. 167 Malang Tlp. 0341567486

e-mail: dama_asikin@ub.ac.id

\begin{abstract}
Abstrak
Kajian ini dilakukan untuk mengidentifikasi konsep arsitektur hijau yang ada di kawasan permukiman pada Daerah Aliran Sungai (DAS) Brantas Kota Malang sebagai permukiman informal. Dengan menggunakan Theory of Ekistics - Doxiadis, perolehan hasil kajian awal pencarian elemen-elemen pembentuk permukiman berupa: a) Lingkungan alam: sungai, topografi, RTH, orientasi bangunan, dan kepadatan bangunan; b) Lindungan: hunian/rumah tinggal dan fasilitas umum; dan c) Jejaring: sistem drainase, MCK, SPAB, jaringan jalan, TPS, jaringan listrik. Parameter konsep arsitektur hijau yang digunakan didasarkan pada konsep arsitektur hijau untuk permukiman maupun Greenship Rating Tools Untuk Gedung Terbangun Versi 1.0. Pada elemen lingkungan alam terdapat 2 parameter dengan nilai maksimum 4; pada elemen lindungan terdapat 2 parameter dengan nilai maksimal 2; dan pada elemen jejaring terdapat 4 parameter dengan nilai maksimal 10.Penilain parameter pada elemen lindungan mencapai nilai maksimal 1.5 dari 2 atau $75 \%$ dikarenakan pemanfaatan potensi sungai sebagai fasilitas umum - rekreasi pemancingan yang juga menggunakan bangunan dengan bahan bangunan alami dan berbentuk shelter yang terbuka. Sedangkan elemen jejaring yang sebenarnya merupakan elemen dominan dalam kawasan ini tidak mencapai nilai yang maksimal dikarenakan belum dimanfaatkan secara optimal potensi alam, terutama sungai, untuk meningkatkan kualitas lingkungan. Sedangkan elemen lingkungan alam memperoleh nilai yang paling kecil dikarenakan kepadatan bangunan yang cukup tinggi dan permukiman ini berkembang tanpa perencanaan.
\end{abstract}

Kata kunci: konsep arsitektur hijau, permukiman DAS Brantas, Malang

\begin{abstract}
The review was conducted to identify the concept of green architecture in the area of settlement on Watershed (DAS) Brantas Malang as informal settlements. Using the Theory of Ekistics - Doxiadis, acquisition search results of initial study settlements forming elements such as: a) Nature: rivers, topography, green open space, building orientation, and building density; b) Shells: housing / residential and public facilities; and c) Networks: drainage system, toilets, utility networks. Parameters used green architecture concept based on the concept of green architecture for residential and Greenship Rating Tools For Building Built Version 1.0.0. The natural environment have 2 parameters with a maximum value of 4 ; the protection element have 2 parameters with a maximum value of 2 , and the network element have 4 parameters with a maximum value of 10 . Assessment parameters on the protection element reaches a maximum value of 1.5 from 2 or $75 \%$ due to the utilization of the potential of the river
\end{abstract}


as a public facility - Recreational fishing is also using the building with natural materials and shaped shelter is open. While actual network elements is the dominant element in this region does not reach the maximum value has not been used optimally due to the natural potential, especially rivers, to improve environmental quality. While elements of the natural environment to obtain the smallest value due to the relatively high density of buildings and the neighborhood was developed without planning.

Keywords: concept of green architecture, Brantas Watershed Settlement, Malang

\section{Pendahuluan}

Berkembangnya suatu kota menyebabkan meningkatnya arus urbanisasi yang antara lain menimbulkan permasalahan akan perumahan dan permukiman. Masalah pengadaan perumahan dan permukiman bagi masyarakat diselesaikan melalui beberapa program oleh pemerintah secara formal. Namun karena permintaan akan perumahan dan permukiman tersebut belum dapat terpenuhi secara formal, maka masyarakat membangun secara individu baik secara legal maupun ilegal.

Perumahan dan permukiman merupakan bagian dari kehidupan komunitas dan keseluruhan lingkungan sosial. Hunian dalam arti harfiah dapat diidentikkan dengan rumah, sebagai benda mati. Atau dalam konteks ini, hunian dimaksudkan sebagai istilah 'vernacular architecture', yaitu merupakan hasil karya perwujudan kesepakatan seluruh lapisan masyarakat, bukan hasil karya seseorang saja dan merupakan bagian dari aktivitas kehidupan manusia yang menghuninya. Akan selalu terjadi hubungan timbal balik antara penghuni dan huniannya yang tidak lepas dari konsep hubungan manusia dengan lingkungannya.

Arsitektur hijau merupakan salah satu cara yang digunakan untuk mewujudkan arsitektur yang ekologis atau ramah lingkungan demi mencapai keseimbangan di dalam sistem interaksi manusia dengan lingkungan. Arsitektur hijau adalah arsitektur yang minim mengonsumsi sumber daya alam serta minim menimbulkan dampak negatif bagi lingkungan, yang merupakan langkah untuk merealisasikan kehidupan manusia yang berkelanjutan. Aplikasi arsitektur hijau akan menciptakan suatu bentuk arsitektur yang berkelanjutan.

Pada masyarakat tradisional bangunan rumah tinggal merupakan dunia kecil, tempat kehidupan manusia diatur dan dipusatkan (Karyono, 2010). Bangunan rumah hanya merupakan sarana yang diperlukan bagi penyelenggaraan kehidupan manusia secara aman dan nyaman yang akan dibuat sesuai kebutuhan. Keyakinan yang diimplementasikan dalam tindakan-tindakan yang bersifat konservatif merupakan dasar-dasar rancangan arsitektur hijau.

Permukiman atau yang juga disebut sebagai Human Settlement menurut Doxiadis dalam Kuswartojo (2005) merupakan sebuah tempat yang dihuni oleh manusia. Manusia yang bermukim di tempat tersebut akan menentukan jenis permukimannya. Permukiman terdiri dari elemen the content (man dan society) dan the container (nature, shell, dan network). Kelima unsur ini dalam permukiman saling terkait satu sama lainnya, akan tetapi porsi dan komposisi elemen-elemen ini sangat bervariasi, sehingga dapat membentuk permukiman dengan satu karakter tertentu. Dari pemaparan mengenai permukiman tersebut, permukiman tidak hanya dipahami secara 3 dimensi, melainkan dengan 4 dimensi, karena manusia dan masyarakat selalu berubah dan berkembang secara berkelanjutan. 
Keterbatasan lahan tinggal di perkotaan serta faktor ekonomi menyebabkan berkembangnya permukiman secara informal di bantaran sungai maupun sepanjang area rel kereta api. Keberadaan Sungai Brantas yang melintasi kota Malang, menyebabkan daerah aliran sungai Brantas merupakan area yang sangat berkembang menjadi permukiman. Berdasarkan RTRW Kota Malang tahun 2010, direncanakan adanya program penataan permukiman dengan memindahkan penduduk ke daerah yang lebih aman, seperti halnya dengan memberikan alternatif relokasi bangunan di wilayah sempadan sungai 15 meter dan dinyatakan sebagai daerah yang rawan bencana (daerah berbahaya) untuk kemudian dikembangkan sebagai daerah rekreasi dan daerah hijau kota (taman kota), khususnya bagi daerah yang maksimal kelerengannya $30 \%$.

Kawasan permukiman DAS Brantas yang berada di Kelurahan Penanggungan Kota Malang merupakan salah satu permukiman dengan kepadatan tinggi yang terletak dekat dengan pusat kota. Hasil penelitian Kurniawan (2011) menunjukkan bahwa permukiman ini berpotensi untuk dikembangkan sebagai permukiman ekologis di kawasan tepi sungai.

Dari uraian tersebut di atas, maka dirasa perlu untuk melakukan identifikasi konsep arsitektur hijau pada hunian yang ada di kawasan DAS Brantas Kelurahan Penanggungan yang merupakan salah satu permukiman informal hasil karya masyarakat. Dengan demikian masyarakat akan menyadari bahwa sebenarnya secara naluriah mereka sudah menerapkan konsep arsitektur hijau di permukiman mereka sehingga harus dipertahankan bahkan ditingkatkan untuk menjaga dan meningkatkan kualitas hidup dan lingkungannya.

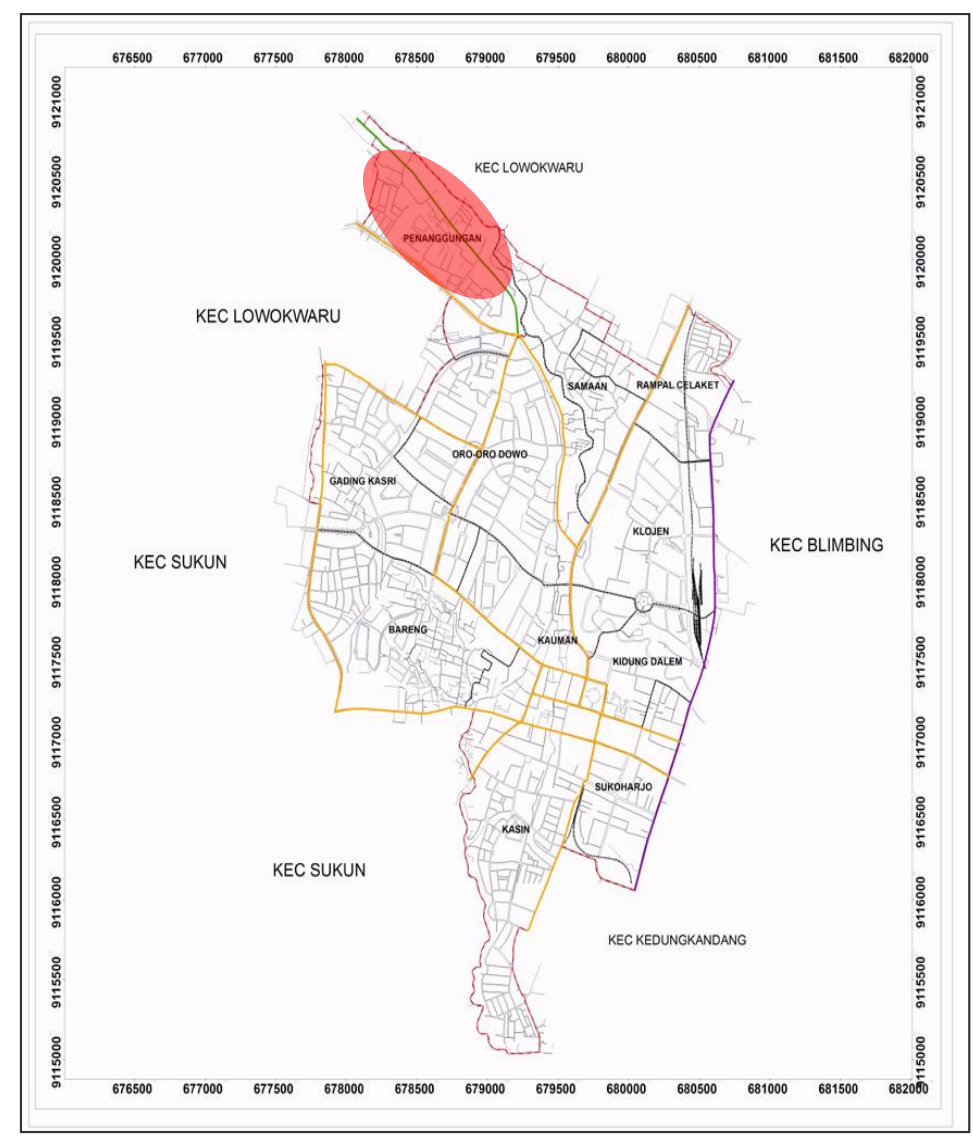

Gambar 1. Lokasi Kelurahan Penanggungan Kecamatan Klojen Kota Malang Sumber : RDTRK Kota Malang 2011 


\section{Bahan dan Metodologi}

Dalam penelitian ini strategi yang digunakan adalah strategy empirical method yang terdiri dari domain case study atau studi kasus. Sebagaimana telah disebutkan secara eksplisit pada judul penelitian, penelitian ini mempunyai sifat menjelajah (exploratory) yang mempunyai permasalahan yang terbuka luas dan belum ada hipotesanya. Metode penelitian yang dipakai adalah metoda survai deskriptif (descriptive survey methods) karena data yang didapatkan akan berasal dari hasil observasi langsung di lapangan. Metode deskriptif digunakan untuk menggambarkan, mengidentifikasi, dan menganalisa konsep arsitektur hijau yang ditemukan di kawasan permukiman DAS Brantas Kelurahan Penanggungan Malang sebagai obyek kajian.

Populasi dalam penelitian ini adalah kawasan lingkungan permukiman DAS Brantas yang berada di kelurahan Penanggungan Malang. Pemilihan sampel (studi kasus) penelitian dilakukan dengan purpossive sampling, yang berarti tidak didasarkan pada besarnya populasi melainkan didasarkan pada ciri-ciri atau karakteristik tertentu.

Pengumpulan data dalam penelitian ini diawali dengan pengamatan elemenelemen pembentuk permukiman berupa lingkungan alam, lindungan, serta networks/jejaring, di seluruh kawasan penelitian. Pemilihan sampel penelitian menggunakan metode purposive sampling ditentukan setelah diperoleh gambaran secara keseluruhan elemen permukiman yang ada.

Setelah sampel ditentukan, dilanjutkan dengan observasi dan pendokumentasian /survei ke lapangan untuk mengamati secara langsung situasi dan kondisi yang sebenarnya. Pada tahap observasi ini dilakukan pengamatan dan pencatatan konsep arsitektur hijau apa saja yang bisa diidentifikasi pada elemen pembentuk permukiman yang ditemukan pada lokasi penelitian.

Langkah selanjutnya mengelompokkan sampel berdasarkan variabel konsep arsitektur hijau sesuai dengan elemen pembentuk permukimannya. Setelah itu, hasil pengelompokan dianalisa berdasarkan parameter arsitektur hijau.

\section{Hasil dan Pembahasan}

Kota Malang merupakan salah satu kota pendidikan dan pariwisata di Jawa Timur yang mengalami pertumbuhan dan perkembangan kota yang sangat cepat baik dalam pertumbuhan fisik maupun ekonomi. Hal itu menyebabkan kaum urban tertarik untuk datang dan mencari nafkah di Kota Malang sehingga menyebabkan semakin padatnya jumlah penduduk.

Kehadiran kaum pendatang yang tidak selalu diimbangi dengan pengetahuan dan pendidikan yang memadai dalam bersaing untuk mencari nafkah menyebabkan timbul kelompok masyarakat kurang mampu berpenghasilan rendah. Keadaan tersebut semakin diperburuk dengan terbatasnya lahan sebagai wadah kegiatan hidup dan tempat tinggal yang mengakibatkan tingginya harga tanah dan rumah di Kota Malang. Hal ini menimbulkan terbentuknya kampung kota yang umumnya diidentifikasikan sebagai suatu daerah yang padat penduduk dengan tingkat ekonomi yang relatif rendah di daerah marjinal seperti daerah aliran sungai maupun pinggir rel kereta api.

Kelurahan Penanggungan termasuk kawasan Kecamatan Klojen (lihat Gambar 5.1). Luas wilayahnya sekitar 78,25 Ha (8,9\% dari luas wilayah Kecamatan Klojen). Batas administratifny: sebelah Utara Kecamatan Lowokwaru, sebelah Selatan Kelurahan OroOro Dowo, sebelah Timur Kelurahan Samaan dan Kecamatan Lowokwaru, dan sebelah Barat Kecamatan Lowokwaru. Permukiman ini merupakan permukiman yang telah lama terbentuk meskipun sebenarnya berada di area yang tidak boleh dibangun. Berdasarkan 
RDTR Kecamatan Klojen, area tapak merupakan area kawasan lindung sepanjang daerah aliran Sungai Bantas untuk menjaga kelangsungan ekosistem sekaligus menjadi filter dan menjaga kualitas air sungai.
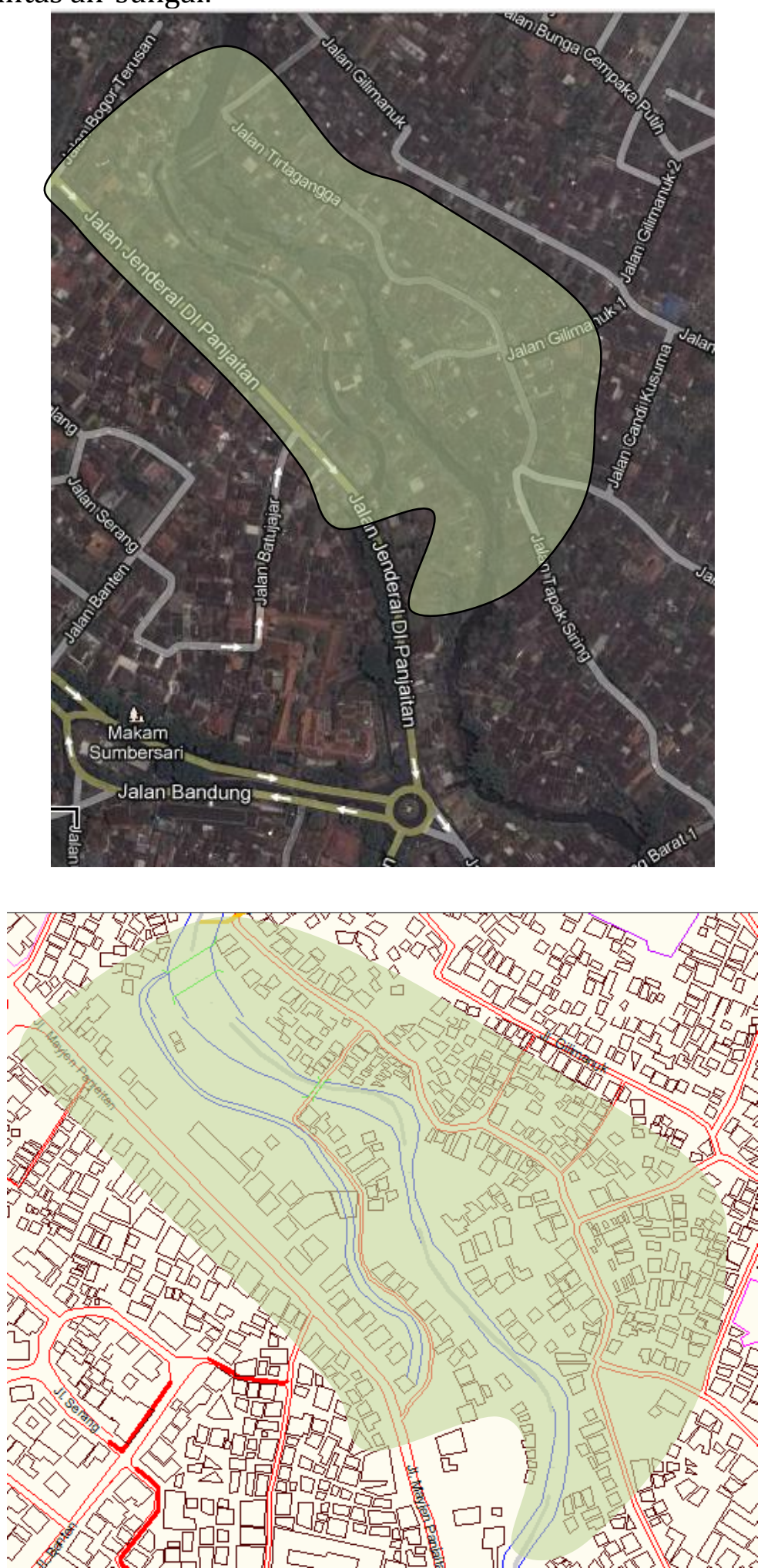

Gambar .2. Kawasan lokasi studi

Sumber : Google Earth,2012 \& RTRW Kota Malang Tahun 2007 
Berdasarkan Theory of Ekistics - Doxiadis (Kuswartojo, 2005) permukiman terdiri dari 5 elemen yang bisa dikelompokkan dalam the content dan the container, yang harus dipahami secara keseluruhan, tidak dibedakan secara tegas dalam kajiannya. Akan tetapi karena dalam penelitian kali ini lebih menitikberatkan pada fisik kawasan permukimannya, maka pembahasan lebih mendalam dalam elemen the container. Walaupun demikian elemen the content tidak dapat sama sekali diabaikan atau tidak dibahas karena pada dasarnya the content dan the container merupakan satu kesatuan pembentuk permukiman. Hasil penelusuran di lapangan, maka elemen fisik pembentuk lingkungan bisa dilihat dalam tabel 1.

\section{Tabel 1: Elemen pembentuk permukiman}

Elemen Fisik Pembentuk Lingkungan

Hasil identifikasi di wilayah kajian

1 Lingkungan alam / nature Sungai

Topografi lahan kawasan berkontur (15 - $40 \%)$

Ruang terbuka / kawasan resapan 2499.16 m2 (38\%)

Orientasi bangunan timur - barat

Kepadatan bangunan tinggi di sepanjang tepi sungai

2 Lindungan / shell

Rumah tinggal / hunian

Fasilitas umum

3 Jejaring / networks

Sistem drainase Kanal + Dam Kadalpang (makro)

dan sistem drainase mikro

MCK umum

SPAB: PDAM + sumur air bersih

Jalan lingkungan + jalan setapak

TPS

Listrik

Penentuan parameter konsep arsitektur hijau menggunakan hasil analisis dari konsep arsitektur hijau menurut Kurniawan (2011) serta parameter yang ditetapkan oleh Greenship Rating Tools untuk Gedung Terbangun Versi 1.0. - 2011 yang disesuaikan dengan obyek kajian. Obyek kajian dalam penelitian kali ini bersifat makro, sehingga parameter yang bersifat mikro/ skala unit bangunan tidak akan digunakan.

Setelah ditetapkan parameter arsitektur hijau yang digunakan dalam kajian ini (Tabel 2), maka dilakukan analisa parameter-parameter tersebut pada elemen pembentuk permukiman yang menjadi obyek kajian. Hasil identifikasi konsep arsitektur hijau pada elemen pembentuk permukiman selanjutnya diberikan nilai sesuai dengan nilai parameter yang sudah ditetapkan. Dari jumlah nilai yang didapatkan akan bisa diidentifikasi konsep arsitektur hijau pada elemen pembentuk permukiman tersebut

Tabel 2: Parameter Arsitektur Hijau yang digunakan

\begin{tabular}{lllc}
\hline No & $\begin{array}{l}\text { Elemen - Elemen Fisik Lingkungan } \\
\text { Permukiman }\end{array}$ & Parameter & Nilai \\
\hline 1 & Nature / Lingkungan Alam & - Memperbanyak ruang terbuka hijau sebagai area & $\mathbf{4}$ \\
\hline & & $\begin{array}{l}\text { resapan tanah } \\
\text { - Pengadaan sumber air untuk memenuhi kebutuhan air }\end{array}$ & 1 \\
\hline $\mathbf{2}$ & Shells / Lindungan & $\mathbf{2}$ & 1 \\
\hline & $\begin{array}{l}\text { (rumah, fasilitas umum, tempat } \\
\text { jugreasi, perkantoran, industri, dan }\end{array}$ & $\begin{array}{l}\text { - Memperbanyak fasilitas umum yang dipergunakan } \\
\text { untuk kepentingan bersama }\end{array}$ & 1 \\
\hline & & $\begin{array}{l}\text { - Pemanfaatan lahan yang ada sesuai dengan } \\
\text { peruntukannya }\end{array}$ & \\
\hline
\end{tabular}




\begin{tabular}{llc}
\hline Networks / Jejaring & $\mathbf{1 0}$ \\
\hline & $\bullet$ Pengaturan pembuangan air hujan & 2 \\
\hline & $\begin{array}{l}\text { Pengelolaan pembuangan dan pengolahan limbah dan } \\
\text { sampah }\end{array}$ & 3 \\
\hline & Pengelolaan penyediaan dan distribusi air bersih & 4 \\
\hline & $\begin{array}{l}\text { Adanya pencatatan rutin bulanan hasil pantau dan } \\
\text { koleksi data pada kWh meter }\end{array}$ & 1 \\
\hline
\end{tabular}

Tabel 3, 4, dan 5 menunjukkan hasil penilaian parameter pada elemen pembentuk permukiman.

Tabel 3: Penilaian Parameter pada Elemen Lingkungan Alam

\begin{tabular}{|c|c|c|c|c|c|c|c|c|}
\hline Lingkungan alam / nature & & Plem & $\begin{array}{l}\text { Pen } \\
\text { luk }\end{array}$ & $\begin{array}{l}\text { entuk } \\
\text { lan }\end{array}$ & & & Nila & \\
\hline Parameter & $\begin{array}{l}\tilde{\pi} \\
\stackrel{\infty}{\infty} \\
\Xi \\
\Xi\end{array}$ & 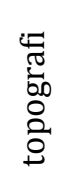 & 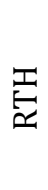 & 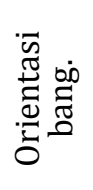 & 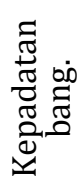 & 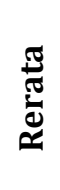 & 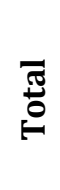 & 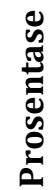 \\
\hline $\begin{array}{l}1 \text { Memperbanyak ruang terbuka hijau } \\
\text { sebagai area resapan tanah }\end{array}$ & 3 & 3 & 3 & & & 0.6 & \multirow{2}{*}{1} & \multirow{2}{*}{25} \\
\hline $\begin{array}{l}2 \text { Pengadaan sumber air untuk memenuhi } \\
\text { kebutuhan air }\end{array}$ & 1 & & & & 1 & 0.4 & & \\
\hline
\end{tabular}

Tabel 4: Penilaian Parameter pada Elemen Lindungan

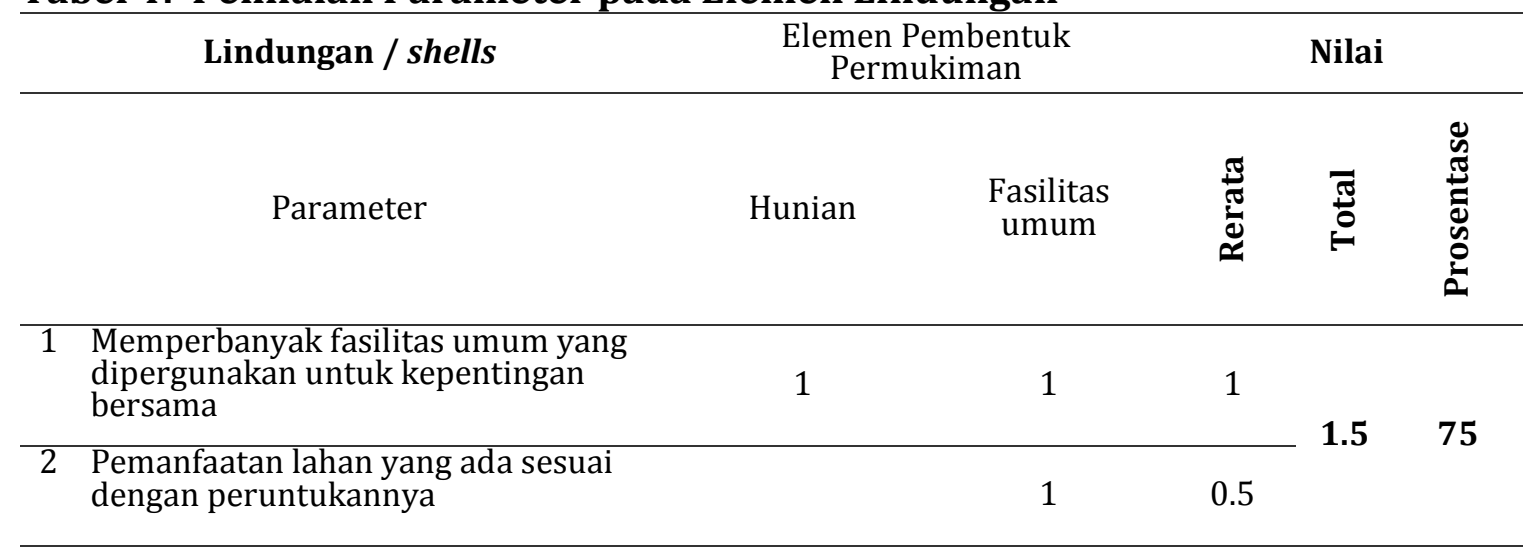

\section{Tabel 5: Penilaian Parameter pada Elemen Jejaring}

\begin{tabular}{|c|c|c|c|c|c|c|c|c|c|c|}
\hline & Jejaring / nettworks & & & en & kim & tuk & & & Nilai & \\
\hline & Parameter & 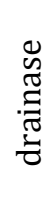 & 光 & 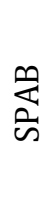 & $\frac{\sqrt[\pi]{\pi}}{. \frac{\pi}{n}}$ & $\stackrel{n}{E}$ & 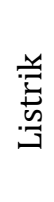 & 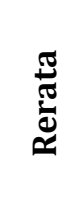 & $\stackrel{\pi}{0}$ & 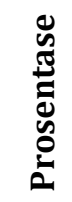 \\
\hline 1 & Pengaturan pembuangan air hujan & 2 & & 2 & 2 & & & 1 & \multirow{4}{*}{4.67} & \multirow{4}{*}{46.7} \\
\hline 2 & $\begin{array}{l}\text { Pengelolaan pembuangan dan } \\
\text { pengolahan sampah }\end{array}$ & & 3 & & 3 & 3 & & 1.5 & & \\
\hline 3 & $\begin{array}{l}\text { Pengelolaan penyediaan dan } \\
\text { distribusi air bersih }\end{array}$ & 4 & 4 & 4 & & & & 2 & & \\
\hline 4 & $\begin{array}{l}\text { Adanya pencatatan rutin bulanan } \\
\text { hasil pantau dan koleksi data pada } \\
\text { kWh meter }\end{array}$ & & & & & & 1 & 0.17 & & \\
\hline
\end{tabular}




\section{Kesimpulan}

Elemen pembentuk permukiman pada kawasan Permukiman DAS Brantas Kelurahan Penanggungan Malang berupa: a) Lingkungan alam: sungai, topografi, RTH, orientasi bangunan, dan kepadatan bangunan; b) Lindungan: hunian/rumah tinggal dan fasilitas umum; dan c) Jejaring: sistem drainase, MCK, SPAB, jaringan jalan, TPS, jaringan listrik

Elemen pembentuk permukiman berupa jaringan / networks merupakan elemen yang paling dominan dalam kajian ini dikarenakan skala kajian yang bersifat makro. Parameter konsep arsitektur hijau yang digunakan: pada elemen lingkungan alam terdapat 2 parameter dengan nilai maksimum 4; pada elemen lindungan terdapat 2 parameter dengan nilai maksimal 2; dan pada elemen jejaring terdapat 4 parameter dengan nilai maksimal 10.

Penilain parameter pada elemen lindungan mencapai nilai maksimal 1.5 dari 2 atau 75\% dikarenakan pemanfaatan potensi sungai sebagai fasilitas umum - rekreasi pemancingan yang juga menggunakan bangunan dengan bahan bangunan alami dan berbentuk shelter yang terbuka. Sedangkan elemen jejaring yang sebenarnya merupakan elemen dominan dalam kawasan ini tidak mencapai nilai yang maksimal dikarenakan belum dimanfaatkan secara optimal potensi alam, terutama sungai, untuk meningkatkan kualitas lingkungan. Sedangkan elemen lingkungan alam memperoleh nilai yang paling kecil dikarenakan kepadatan bangunan yang cukup tinggi dan permukiman ini berkembang tanpa perencanaan.

\section{Daftar Pustaka}

Konsil Bangunan Hijau Indonesia. 2011. Greenship Existing Building Version 1.0 Ringkasan Tolok Ukur. Divisi Rating \& Teknologi, Green Building Council Indonesia

Kurniawan, David. 2011. Kampung Kota dengan Konsep Ekologis pada Kawasan Tepi Aliran Sungai di Kelurahan Penanggungan Malang. Skripsi (tidak dipublikasikan), Arsitektur FT Universitas Brawijaya, Malang.

Kuswartojo, Tjuk.; Rosnarti, Dwi; Effendi, Vinondini; Eko K, Rasiono; Sidi, Purnomo. 2005. Perumahan dan Permukiman di Indonesia; Upaya membuat perkembangan kehidupan yang berkelanjutan. ITB, Bandung

Kuswartojo, Tjuk. 2010. Permukiman dan perkotaan: Mengusik Tata Penyelenggaraan Lingkungan Hidup dan Pemukiman. ITB, Bandung

US Green Building Council. 2009. LEED 2009 for New Construction \& Major Renovations Rating Systems, Washington 